\title{
Plasma Lipoprotein Induction and Suppression of the Generation of Cellular Procoagulant Activity In Vitro
}

\author{
TWO PROCOAGULANT ACTIVITIES ARE PRODUCED BY \\ PERIPHERAL BLOOD MONONUCLEAR CELLS
}

\author{
Bradford S. Schwartz, Gary A. Levy, Linda K. Curtiss, Daryl S. Fair, \\ and Thomas S. EDgington, Department of Molecular Immunology, \\ Research Institute of Scripps Clinic, La Jolla, California 92037
}

\begin{abstract}
A B S T RAC T In the process of analyzing the effects of lipoproteins on functions of lymphoid cells, it was observed that physiological concentrations of isolated human plasma lipoproteins possess varying capacities to rapidly enhance the expression of procoagulant activity of human peripheral blood mononuclear cells in vitro. In a strict dose-dependent fashion, very low density lipoprotein, intermediate density lipoprotein, and high density lipoprotein enhanced both the surface expression by viable cells and the total cellular content of procoagulant activity during a 6 -h incubation. Very low density lipoprotein induced a maximal 6.7-fold increase in the expression of a thromboplastin activity, which was consistent with tissue factor, in that it was dependent on Factors VII, X, and II. Both intermediate density lipoprotein and high density lipoprotein induced approximately a 12-fold increase of a different procoagulant activity which appears to be a direct prothrombin activator. This prothrombinase was calcium dependent and was inhibited by $2.5 \mathrm{mM}$ diisopropylfluorophosphate, but was not neutralized by antiFactor X antibodies or by inhibitors of Factor Xa. In contrast to the other lipoprotein density classes, low density lipoprotein did not stimulate procoagulant activity, but instead actively suppressed the generation of the two procoagulant activities induced by the stimulatory lipoproteins. Suppression by low density lipoprotein was clearly evident at molar ratios of low density lipoprotein to stimulatory lipoproteins of $1: 3$ or less. Reconstitution of all lipoproteins to physiological concentrations was not stimulatory as a consequence of the suppressive effects of low density lipoprotein.
\end{abstract}

This is publication 2229 from the Immunology Departments of the Research Institute of Scripps Clinic.

Received for publication 18 October 1980 and in revised form 29 December 1980.
These data indicate that isolated plasma lipoproteins are capable of regulating the expression of two different procoagulant activities of peripheral blood mononuclear cells in vitro. The possibility that these interactions may be implicated in the association between certain types of hyperlipoproteinemias and thromboembolic disease merits study.

\section{INTRODUCTION}

Lymphoid cells, as exemplified by peripheral blood mononuclear cells (PBM), ${ }^{1}$ can be stimulated to generate procoagulant activity (PCA) by a variety of stimuli including lipopolysaccharide (LPS) (1-3), antigenantibody complexes (4), mitogenic lectins (5), and proteolytic products of complement (C) 5 (6). The LPSinduced procoagulant activity of human mononuclear cells has been characterized as a tissue thromboplastin that binds plasma Factor VII and initiates the sequence of enzymatic cleavages of the extrinsic pathway of blood coagulation (7). These events culminate in the conversion of prothrombin to the serine protease thrombin, which induces the formation of an insoluble fibrin gel from soluble fibrinogen and also induces platelet aggregation.

Lipids participate significantly in the assembly of proteins of the coagulation sequence as exemplified by their requisite role as a cofactor in the proteolytic generation of activated Factor $\mathrm{X}$, as well as the assembly of $\mathrm{Xa}, \mathrm{Va}$, and prothrombin to generate thrombin (8).

\footnotetext{
${ }^{1}$ Abbreviations used in this paper: HDL, high density lipoprotein; IDL, intermediate density lipoprotein; LDL, low density lipoprotein; LPS, lipopolysaccharide; PAGE, polyacrylamide gel electrophoresis; PBM, peripheral blood mononuclear cells; PCA, procoagulant activity; VLDL, very low density lipoprotein.
} 
In studies of the effects of plasma lipoproteins on intrinsic blood coagulation, lipoproteins have been observed to accelerate coagulation in a number of plasma clotting assays $(9,10)$. Plasma lipoproteins are also potent immunoregulatory molecules and are capable of affecting a variety of lymphocyte functions both in vitro and in vivo (11-14). The effects, however, of plasma lipoproteins on the expression of PCA by PBM have not been recognized.

In the process of analyzing the regulation of lymphocyte function by plasma lipoproteins, it was observed that certain classes of isolated lipoproteins could induce the generation of PCA by PBM in culture, whereas others could not. We here report these in vitro observations and speculate on the possible in vivo implications of this newly described phenomenon. An accompanying paper describes the cellular requirements for plasma lipoprotein induction and suppression of this cellular PCA expression.

\section{METHODS}

Lipoproteins. Fresh human plasma was obtained from normal healthy donors by plasmaphoresis and adjusted to $0.1 \%$ EDTA (wt/vol). The lipoproteins were separated by sequential ultracentrifugation of the plasma at densities of $1.006,1.019,1.063$, and $1.21 \mathrm{~g} / \mathrm{ml}$ using solid $\mathrm{KBr}$ for density adjustment (15) in heat-sealed polyallomer tubes. Isolation first used centrifugation in a 45-Ti rotor (Beckman Instruments, Inc., Fullerton, Calif.) at $42,000 \mathrm{rpm}$ and finally a Beckman $60-\mathrm{Ti}$ rotor at $58,000 \mathrm{rpm}$ for $16-40 \mathrm{~h}$ at $4^{\circ} \mathrm{C}$. The fractions were dialyzed thoroughly against lipoprotein buffer containing $0.15 \mathrm{M} \mathrm{NaCl}, 0.15 \mathrm{mM}$ EDTA, $0.0005 \%$ alphatocopherol, $\mathrm{pH} 7.4$, and filter sterilized $(0.45-\mu \mathrm{m}$ filters, Millipore Corp., San Francisco, Calif.). The lipoprotein fractions included very low density lipoprotein (VLDL, $d<1.006$ $\mathrm{g} / \mathrm{ml}$ ), intermediate density lipoprotein (IDL, $d=1.006-$ $1.019 \mathrm{~g} / \mathrm{ml}$ ), low density lipoprotein (LDL, $d=1.019-1.063$ $\mathrm{g} / \mathrm{ml}$ ), and high density lipoprotein (HDL, $d=1.063-1.21$ $\mathrm{g} / \mathrm{ml}$ ). The preparations were analyzed for protein content by a modification (16) of the Lowry method using a bovine albumin standard. All preparations were characterized by lipoprotein electrophoresis in $1 \%$ agarose (17) and analyzed for relative purity by double diffusion in gel with monospecific rabbit antisera to human albumin and IgG (detection limit of 1.7 and $15 \mu \mathrm{g} / \mathrm{mg}$ lipoprotein protein, respectively, and if free of these contaminating proteins, used and stored sterile at $4^{\circ} \mathrm{C}$ for no $>20 \mathrm{~d}$. Plasma coagulation factor contamination of the isolated lipoproteins was monitored as described below.

Endotoxin contamination of the lipoproteins was monitored by both mouse lethality and limulus assays. The mouse lethality assay (18) was performed with groups of five 6-8wk-old C3H/St male mice injected with $10 \mu \mathrm{g}$ actinomycin D i.p. (Calbiochem-Behring Corp., San Diego, Calif.), followed in $1 \mathrm{~h}$ by the test material. LPS was used as a positive control and was detectable at a concentration of $10 \mathrm{ng}$ in the absence or presence of $>2 \mathrm{mg}$ of lipoprotein protein. No endotoxin contamination of any of the lipoproteins was observed. Lipoproteins were delipidated at $22^{\circ} \mathrm{C}$ by chloroform extraction (19) for assay of endotoxin by the limulus assay (E-toxate, Sigma Chemical Co., St. Louis, Mo.). Controls included LPS, lipoprotein buffer, and saline. While in all instances $1 \mathrm{ng}$ of added LPS was detectable in the presence of $>1 \mathrm{mg}$ of each of the lipoproteins, endogenous endotoxin contamination of the lipoproteins was undetectable at $<1 \mathrm{ng} / \mathrm{mg}$ of lipoprotein protein.

Cell isolation and culture conditions. Human PBM were isolated from the blood of fasting healthy donors by centrifugation over Ficoll-Hypaque $(20)$ at $1,400 \mathrm{~g}$ at $22^{\circ} \mathrm{C}$ for 12 min, washed three times with RPMI-1640 (Grand Island Biological Co., Grand Island, N. Y.), and resuspended at $1 \times 10^{6}$ cells $/ \mathrm{ml}$ in complete medium (10\% fetal calf serum in PRMI-1640, $100 \mathrm{U} / \mathrm{ml}$ penicillin $50 \mu \mathrm{g} / \mathrm{ml}$ streptomycin). Viability was $>98 \%$ by trypan blue exclusion. The PBM contained an average of $85 \%$ lymphocytes, $12 \%$ monocytes and $3 \%$ or less contaminating polymorphonuclear leukocytes as assessed by cytology, vital uptake of neutral red and nonspecific esterase stains (21).

$\mathrm{PBM}$ at $1 \times 10^{6} / \mathrm{ml}$ were incubated in complete medium at $37^{\circ} \mathrm{C}$ in $6 \% \mathrm{CO}_{2}$ in $12 \times 75-\mathrm{mm}$ polypropylene tubes (Falcon Labware, Div. Beckton Dickinson \& Co., Oxnard, Calif.). $6 \mathrm{~h}$ after the addition of test material, the cells were washed twice with RPMI-1640, unless otherwise indicated, and cell viability assessed by trypan blue exclusion before assay of cellular PCA. Bacterial LPS (Escherichia coli 0111 B4, butanol extracted) was kindly provided by Dr. David Morrison, Emory University, Atlanta, Ga. It was used as a positive control at a final concentration of $10 \mu \mathrm{g} / \mathrm{ml}$.

Procoagulant activity. PCA was quantitated in a one-stage clotting assay (3). The PBM were assayed for either viable or total content. For assay of viable cells the washed cell pellet was resuspended in $1.0 \mathrm{ml}$ of RPMI-1640. For assay of total cellular content, the washed cell pellet was frozen at $-70^{\circ}$ and thawed at $37^{\circ} \mathrm{C}$ three times and then sonicated in $0.5 \mathrm{ml}$ RPMI-1640 under previously determined optimal conditions with a microtip probe of a model W-140 sonicator (Heat Systems-Ultrasonics, Inc., Plainview, N. Y.) at a setting of 3 using two 10-s bursts, each with ice cooling. A second $0.5 \mathrm{ml}$ of RPMI-1640 was added to bring the final volume to $1.0 \mathrm{ml}$. In brief, the clotting assay (3) consisted of $0.1 \mathrm{ml}$ cell sample (either viable or homogenized cells) and $0.1 \mathrm{ml}$ of citrated normal human platelet-poor plasma, or factor-deficient plasma (George King Biomedical Inc., Overland Park, Kan.) The reaction was initiated by the addition of $0.1 \mathrm{ml}$ of $25 \mathrm{mM} \mathrm{CaCl}_{2}$ and the time (in seconds) for the initial appearance of an insoluble fibrin clot with manual rocking at $37^{\circ} \mathrm{C}$ was recorded. A rabbit brain thromboplastin standard at $36 \mathrm{mg}$ dry mass $/ \mathrm{ml}$ (Dade Div., American Hospital Supply Corp., Miami, Fla.) was assigned a value of $100,000 \mathrm{mU}$. Clotting times for 0 and $10,000 \mathrm{mU}$ of thromboplastin were 196 and $24 \mathrm{~s}$, respectively. Data are expressed as the mean and standard deviation of replicate assays. Precision of the assay varied from 6.1 to $9.7 \%$ (coefficient of variation). RPMI-1640 with or without $10 \%$ fetal calf serum, lipoprotein buffer, and $10 \mu \mathrm{g} / \mathrm{ml} \mathrm{LPS}$ were without PCA, based on the clotting time of recalcified platelet-poor plasma. In addition, coagulation of recalcified normal platelet-poor plasma was not accelerated in the presence of $1.0,1.25,3.0$, and $3.1 \mathrm{mg}$ protein of intact VLDL, IDL, LDL, and HDL, respectively. Contamination of the lipoproteins with plasma coagulation Factors VII, IX, and X was assayed by standard prothrombin time and by activated partial thrombplastin time (22) with the aid of hereditary factor-deficient plasmas. The limits of detection were determined from standard curves established by supplementing the deficient plasmas with $0.1-20 \%$ normal human plateletpoor plasma. The limits of detection were $0.2 \%$ for Factor VII, $0.1 \%$ for Factor IX and $0.4 \%$ for Factor X. There was no correction of the assays in the presence of VLDL, IDL, or $\mathrm{HDL}$ at the above concentrations. On an assumption of normal plasma concentrations of $\sim 10,3$, and $10 \mu \mathrm{g} / \mathrm{ml}$ for Factors VII, IX, and $X$, respectively (22); the lipoproteins were free of functional Factor VII, IX, and X activity at levels of $0.02 \mu \mathrm{g}$ 
Factor VII, $0.003 \mu \mathrm{g}$ Factor IX, and $0.04 \mu \mathrm{g}$ Factor $\mathrm{X} / \mathrm{mg}$ of lipoprotein protein.

Assay of direct prothrombin cleavage. Factor X and prothrombin were isolated from Cohn Fraction III as previously described (23) and were separated from each other by chromatography on heparin-agarose equilibrated in $0.02 \mathrm{M}$ 2(N-morpholino) ethane sulfonic acid/Tris, pH 5.9, containing $0.1 \mathrm{M} \mathrm{NaCl}, 2 \mathrm{mM}$ benzamidine, and $0.02 \% \mathrm{NaN}_{3}$. Immediately before chromatography, the protein solution was adjusted to $2.5 \mathrm{mM} \mathrm{CaCl}$. The column was developed with a linear salt gradient from $0.1-1.0 \mathrm{M} \mathrm{NaCl}$ in the equilibration buffer containing $2.5 \mathrm{mM} \mathrm{CaCl}$. The nonbinding fraction contained prothrombin which was then rechromatographed over a second heparin-agarose column in $0.02 \mathrm{M} 2(\mathrm{~N}$ morpholino) ethane sulfonic acid/Tris, pH 6.0, containing $0.02 \% \mathrm{NaN}_{3}, 2 \mathrm{mM}$ benzamidine, and $2 \mathrm{mM} \mathrm{CaCl}$. The protein was eluted with a linear $0-0.3 \mathrm{M} \mathrm{NaCl}$ gradient in this buffer. Human fibrinogen was isolated by the method of Doolittle et al. (24). Factor Xa was derived from Factor X by cleavage with Russell's viper venom (kindly provided by Dr. W. Kisiel and Dr. E. W. Davie, University of Washington, Seattle, Wash.) followed by gel filtration on Sephadex G-100. Factor $\mathrm{Xa}$, prothrombin, and fibrinogen were of a high degree of purity, as judged by polyacrylamide gel electrophoresis in the presence $0.1 \%$ sodium dodecyl sulfate (SDS) under reduced and nonreduced conditions as described below.

For assay of cleavage, prothrombin was radioiodinated enzymatically with immobilized lactoperoxidase and glucose oxidase (Enzymobeads, Bio-Rad Laboratories, Richmond, Calif.) to a specific activity of $5.9 \mu \mathrm{Ci} / \mu \mathrm{g}$. Cellular homogenates of the variously stimulated PBM were prepared as for assay of the total cellular content of PCA. Fetal calf serum was not included in these cell cultures. ${ }^{125} \mathrm{I}$-Prothrombin $(10 \mu \mathrm{l}$ of $0.1 \mathrm{mM}, \sim 0.425 \mu \mathrm{Ci}), \mathrm{CaCl}_{2}(10 \mu \mathrm{l}$ of $25 \mathrm{mM})$, and cell homogenate $(50 \mu \mathrm{l})$ were combined and incubated at $37^{\circ} \mathrm{C}$ for $30 \mathrm{~min}$. Human Factor Xa $(0.5 \mu \mathrm{g} / \mathrm{ml})$, in the presence of homogenates of $10^{6}$ unstimulated PBM, was used as a positive control for ${ }^{125}$ I-prothrombin cleavage. Each reaction mixture was placed in a single lane of a $0.1 \%$ SDS, $7.5 \%$ polyacrylamide slab gel prepared according to Laemmli (25). Following electrophoresis, the gels were fixed, dried, and analyzed by autoradiography for ${ }^{125} \mathrm{I}$-prothrombin and its cleavage products.

To assess the susceptibility of IDL- or HDL-induced PCA to various protease inhibitors, $50-\mu$ l aliquots of cell homogenate from HDL- or IDL-stimulated PBM were incubated with each of the following protease inhibitors: antithrombin III $(10 \mu \mathrm{g} / \mathrm{ml})$ in the presence or absence of I $\mathrm{U} / \mathrm{ml}$ heparin, trasylol $(10 \mathrm{U} / \mathrm{ml})$, soybean trypsin inhibitor $(10 \mu \mathrm{g} / \mathrm{ml})$, benzamidine (1 $\mathrm{mM})$, phenylmethylsulfonyl fluoride (1 $\mathrm{mM})$, and diisopropylfluorophosphate $(2.5$ and $10 \mathrm{mM})$. After $5 \mathrm{~min}$ incubation with the inhibitor at $22^{\circ} \mathrm{C}, 10 \mu \mathrm{l}$ of $0.1 \mathrm{mM}$ ${ }^{125}$ I-prothrombin and $10 \mu \mathrm{l}$ of $25 \mathrm{mM} \mathrm{CaCl}_{2}$ were added, and the reactions were incubated an additional $30 \mathrm{~min}$ at $37^{\circ} \mathrm{C}$. ${ }^{125}$ I-Prothrombin cleavage was assessed by SDS-polyacrylamide gel electrophoresis (PAGE) and autoradiography. Percent inhibition of ${ }^{125} \mathrm{I}$-prothrombin cleavage was determined from the autoradiographs by soft laser scanning densitometry (Zeineh soft laser, Biomed Instruments, Inc., Chicago, Ill.). Human Factor Xa $(0.5 \mu \mathrm{g} / \mathrm{ml})$, in the presence of homogenates of unstimulated cells, was treated identically for comparison.

Antibody neutralization of PCA was examined using rabbit antisera to human Factor X (23). The IgG fraction of normal rabbit serum $(1 \mathrm{mg} / \mathrm{ml})$, or the $I g G$ fraction of rabbit antiFactor $\mathrm{X}$ immune serum ( $1 \mathrm{mg} / \mathrm{ml}$ with a 1:64 titer for half neutralization of normal human plasma) was added to Human Factor Xa $\left(0.5 \mu \mathrm{g} / \mathrm{ml}\right.$ in the presence of homogenates of $10^{6}$ unstimulated PBM), or to homogenates of IDL- or HDLexposed PBM $\left(10^{6}\right.$ cells $\left./ \mathrm{ml}\right)$. Aliquots were removed im- mediately, and after $6 \mathrm{~h}$ of incubation at $22^{\circ} \mathrm{C}$, combined with ${ }^{125} \mathrm{I}$-prothrombin and $\mathrm{CaCl}_{2}$ at $37^{\circ} \mathrm{C}$ for $45 \mathrm{~min}$, and subjected to SDS-PAGE to assess ${ }^{125}$ I-prothrombin cleavage at each time point. Percent prothrombin cleavage was quantitated from autoradiographs by soft laser densitometry.

Viable cells and cell homogenates of basal and stimulated PBM were also tested for functional direct prothrombin activation. Fibrinogen $(50 \mu \mathrm{l}$ of $4 \mathrm{mg} / \mathrm{ml})$, prothrombin $(50 \mu \mathrm{l}$ of $100 \mu \mathrm{g} / \mathrm{ml})$, and the intact cells or cell homogenates $(100 \mu \mathrm{l})$ were combined in a glass tube. Calcium chloride $(100 \mu \mathrm{l}$ of $25 \mathrm{mM}$ ) was added to initiate the reaction at $37^{\circ} \mathrm{C}$, and the time (in seconds) required for the appearance of insoluble fibrin with manual rocking was recorded.

\section{RESULTS}

Lipoprotein stimulation of procoagulant activity. Isolated PBM expressed low (basal) levels of PCA which was demonstrated by assay of either viable cells or disrupted cell homogenates (Table I). PBM cultured for $6 \mathrm{~h}$ at $37^{\circ} \mathrm{C}$ in the presence of $10 \mu \mathrm{g} / \mathrm{ml} \mathrm{LPS}$, a known inducer of cellular PCA (2), exhibited at 7.4and 15.3-fold increase in the viable expression and total cellular content of PCA, respectively (Table I). The PCA increase induced by LPS was identified using clotting factor-deficient plasmas as a Factor VII-, X-, and II-dependent activity (Table II) which was consistent with the generation of tissue factor as previously described $(2,7)$.

Individual density classes of human plasma lipoproteins isolated by standard differential ultracentrifugation demonstrated varying capacities to induce PCA when they were added to the PBM cultures. Both the viable expression and the total cellular content of PCA increased in response to incubation for $6 \mathrm{~h}$ at $37^{\circ} \mathrm{C}$ with either VLDL, IDL, or HDL, whereas no significant increase was noted with LDL (Table I). Expression of PCA by assay of intact viable cells was in all cases

TABLE I

Induction of Procoagulant Activity in Human PBM Cells by LPS and Plasma Lipoproteins*

\begin{tabular}{|c|c|c|c|}
\hline \multirow[b]{2}{*}{ Stimulus } & \multirow[b]{2}{*}{ Concentration $\downarrow$} & \multicolumn{2}{|c|}{ PCA } \\
\hline & & Viable & Total content \\
\hline & $\mu g / m l$ & \multicolumn{2}{|c|}{$m U / 10^{\circ} P B M$} \\
\hline Buffer£ & - & $42 \pm 20$ & $160 \pm 40$ \\
\hline LPS & 10 & $310 \pm 80$ & $2,450 \pm 500$ \\
\hline VLDL & 190 & $115 \pm 15$ & $845 \pm 75$ \\
\hline IDL & 748 & $275 \pm 55$ & $4,250 \pm 450$ \\
\hline LDL & 1,740 & $75 \pm 35$ & $135 \pm 40$ \\
\hline HDL & 1,975 & $280 \pm 30$ & $3,600 \pm 950$ \\
\hline
\end{tabular}

* PBM containing $85 \%$ lymphocytes and $12 \%$ monocytes were cultured for $6 \mathrm{~h}$ at $37^{\circ} \mathrm{C}$ in complete medium.

† LPS concentration, dry weight per milliliter; lipoprotein concentration, microgram protein per milliliter.

\$ Lipoprotein buffer (LLB). 
TABLE II

Nature of Procoagulant Activity in Human Peripheral Mononuclear Cells Induced by LPS and Plasma Lipoproteins

\begin{tabular}{|c|c|c|c|c|c|c|}
\hline \multirow[b]{3}{*}{ Stimulus } & \multicolumn{6}{|c|}{ Total PCA content* } \\
\hline & \multirow{2}{*}{$\begin{array}{l}\text { Normalt } \\
\text { plasma }\end{array}$} & \multicolumn{5}{|c|}{ Factor-deficient plasma } \\
\hline & & $\mathrm{x}$ & IX & VIII & VII & II \\
\hline & \multicolumn{6}{|c|}{$m U / 10^{6} P B M$} \\
\hline $\begin{array}{l}\text { Buffer } \$ \\
\text { LPS, } 10\end{array}$ & 185 & 150 & 180 & 170 & 150 & 130 \\
\hline $\begin{array}{c}\mu \mathrm{g} / \mathrm{ml} \\
\text { VLDL, } \\
190\end{array}$ & 3,600 & 150 & 3,500 & 3,150 & 220 & 110 \\
\hline $\begin{array}{c}\mu \mathrm{g} / \mathrm{ml} \\
\text { IDL, } \\
\mathbf{7 4 8}\end{array}$ & 1,400 & 120 & 1,400 & 1,510 & 160 & 90 \\
\hline $\begin{array}{c}\mu \mathrm{g} / \mathrm{ml} \\
\mathrm{LDL}, \\
1,740\end{array}$ & 4,100 & 3,200 & 4,400 & 4,100 & 3,800 & 160 \\
\hline $\begin{array}{c}\mu \mathrm{g} / \mathrm{ml} \\
\mathrm{HDL}, \\
1,975\end{array}$ & 175 & 140 & 110 & 110 & 150 & 80 \\
\hline$\mu \mathrm{g} / \mathrm{ml}$ & 3,200 & 2,750 & 3,400 & 3,200 & 2,900 & 140 \\
\hline
\end{tabular}

* PBM containing $83 \%$ lymphocytes and $14 \%$ monocytes were cultured for $6 \mathrm{~h}$. at $37^{\circ} \mathrm{C}$ in complete medium.

\$ Normal platelet-poor plasma.

$\S$ Lipoprotein buffer (LLB).

$<14 \%$ of the total cellular PCA content. The appearance of PCA in cells exposed to lipoproteins was time dependent (Fig. 1). IDL and HDL induced $>10$-fold increase within the first $8 \mathrm{~h}$ of culture in a manner similar to LPS, while VLDL induced a more moderate 5 -fold increase by $8 \mathrm{~h}$. After $16 \mathrm{~h}$ of culture no further increases occurred. A slight but significant increase

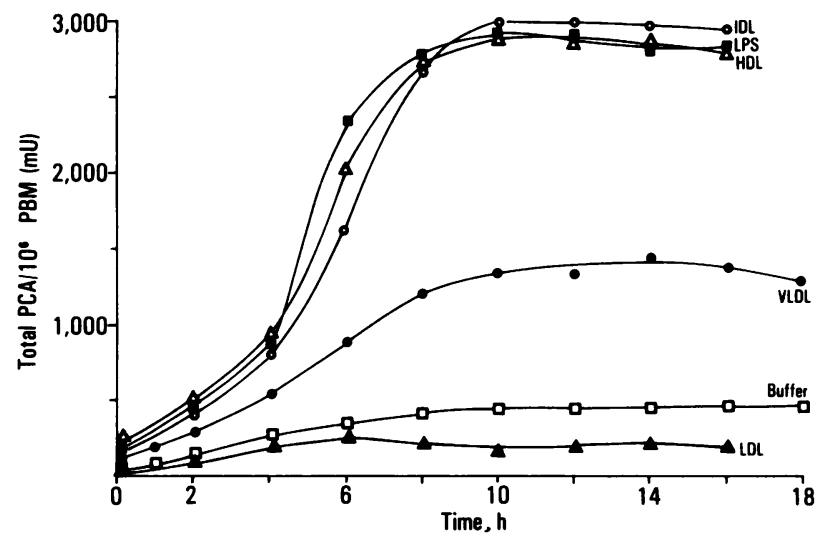

FIGURE 1 Kinetics of lipoprotein induction of PCA in PBM. $1 \times 10^{6} \mathrm{PBM} / \mathrm{ml}$ were cultured at $37^{\circ} \mathrm{C}$ in the presence of lipoprotein buffer, $10 \mu \mathrm{g} / \mathrm{ml}$ LPS, $223 \mu \mathrm{g} / \mathrm{ml}$ VLDL, $909 \mu \mathrm{g} / \mathrm{ml}$ IDL, $949 \mu \mathrm{g} / \mathrm{ml} \mathrm{LDL}$, or $528 \mu \mathrm{g} / \mathrm{ml}$ HDL. At the times indicated, the total cellular PCA content was measured. in the basal (unstimulated) level of PCA was also observed with time, whereas again LDL exhibited no stimulatory activity.

Dose titrations performed on each of the plasma lipoproteins demonstrated a 10 -fold increase in total PCA by incubation with IDL and HDL to 50 and 500 $\mu \mathrm{g}$ protein $/ \mathrm{ml}$, respectively, whereas VLDL induced a maximal 6-fold stimulation at $50 \mu \mathrm{g} / \mathrm{ml}$ (Fig. 2). These protein concentrations of stimulatory lipoproteins were all within the physiological range of normal plasma lipoproteins in adult human plasma (26), and were reproducible within experimental error for six lipoprotein isolations during the course of this study. The observed dose-dependent amplification of PCA was not dependent upon the presence of fetal calf serum in the PBM cell cultures, since similar experiments performed in the absence of serum gave reproducibly comparable results (data not shown).

Suppression of procoagulant activities by $L D L$. In contrast to the stimulatory lipoproteins, LDL at concentrations as high as $1 \mathrm{mg} / \mathrm{ml}$, a supraphysiological concentration (26), induced no increase in PCA over basal levels, and appeared to be somewhat inhibitory at high concentrations (Figs. 1 and 2). To assess this further, the stimulatory lipoproteins were added to PBM cultures containing varying amounts of LDL. The concentrations of stimulatory lipoproteins used were chosen from the dose-response curves (Fig. 2) to give $\sim 95 \%$ of maximum PCA induction, i.e., 50, 50, and $500 \mu \mathrm{g}$ protein/ml for VLDL, IDL, and HDL, respectively. After a 6 -h incubation at $37^{\circ} \mathrm{C},>95 \%$ of the cellular PCA induced by VLDL, IDL, or HDL was prevented by 50,50 , and $200 \mu \mathrm{gDL} / \mathrm{ml}$, respectively. This was not due to direct cellular toxicity since in all cases the cell viability and recovery was $>94 \%$. No inhibition of PCA generation was observed when

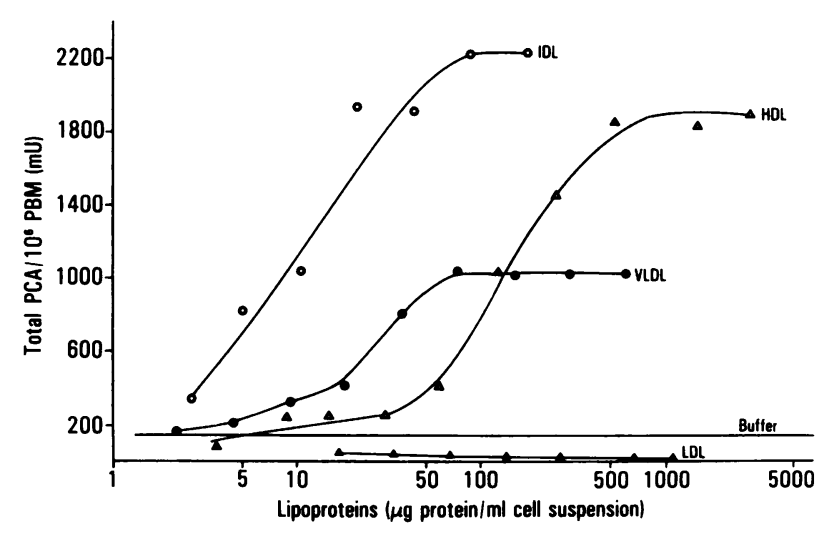

FIGURE 2 The induction of procoagulant activity in PBM by incubation with plasma lipoproteins in vitro is dose dependent. The PBM $\left(1 \times 10^{6}\right.$ in $\left.1 \mathrm{ml}\right)$ were cultured for $6 \mathrm{~h}$ at $37^{\circ} \mathrm{C}$ in the presence of the lipoproteins before assay of total PCA content. 
TABLE III

LDL Inhibits VLDL, IDL, and HDL Stimulation of PBM Cell Procoagulant Activity

\begin{tabular}{lcccc}
\hline & \multicolumn{4}{c}{ Stimulatory lipoproteins } \\
\cline { 2 - 5 } & VLDL & IDL & HDL & $\begin{array}{c}\text { VLDL, } \\
\text { IDL, and HDL }\end{array}$ \\
\hline Concentration $(\mu \mathrm{g} / \mathrm{ml}) *$ & 50 & 50 & 500 & $50,50,500$ \\
Total PCA content $\left(\mathrm{mU} / 10^{6} \mathrm{PBM}\right) \downarrow$ & $2,500 \pm 100$ & $3,950 \pm 350$ & $3,100 \pm 400$ & $2,750 \pm 150$ \\
Amount of LDL $(\mu \mathrm{g} / \mathrm{ml})$ for 50\% suppression* & 8.6 & 8.6 & 38.5 & 16.1 \\
Molar ratio (LDL/stimulus) $\$$ & $1: 3$ & $1: 5$ & $1: 26$ & $1: 44$ \\
\hline
\end{tabular}

* Microgram lipoprotein protein per milliliter.

† The unstimulated total PCA content was $840 \pm 76 \mathrm{mU} / 10^{6} \mathrm{PBM}$.

The molar ratios were calculated using molecular weights of $10 \times 10^{6}, 3.0 \times 10^{6}, 2.5 \times 10^{6}$, and

$5.0 \times 10^{5}$ and percent protein of $10,20,22$, and $50 \%$ for VLDL, IDL, LDL, and HDL, respectively.

the LDL was added at concentrations of $<1.5,3$, and $10 \mu \mathrm{g} / \mathrm{ml}$, respectively. The amount of LDL and the molar ratios of LDL to stimulus which resulted in $50 \%$ inhibition of PCA are summarized in Table III. In each, LDL was active in a dose-dependent fashion at LDL to stimulus molar ratios of $1: 3$ or less, which suggests that LDL need not be present at an equimolar concentration relative to the stimulatory lipoproteins to preclude stimulation. LDL also inhibited, in a dosedependent fashion in the absence of cytotoxicity, the PCA generated by an approximate physiological ratio of all three stimulatory lipoproteins, and in this instance was active at an LDL to stimulus molar ratio of 1:44 (Table III). Thus, the net effect of the simultaneous addition of LDL to either VLDL-, IDL-, and/ or HDL-stimulated PBM cultures was the expression of only basal levels of PCA.

Characterization of the procoagulant activities. The type of PCA generated in PBM by the stimulatory lipoproteins was identified by a one-stage clotting assay using plasmas deficient for single human coagulation factors (Table II). The activity generated by incubation with VLDL was Factor VII, X, and II dependent, which is consistent with activation by tissue factor via the extrinsic coagulation pathway. Similar results were found for LPS-induced PCA. In contrast, most of the activity induced by incubation of PBM with either IDL or HDL occurred via a pathway that appeared independent of Factor VII of the extrinsic coagulation pathway, Factor IX and VIII of the intrinsic pathway, and Factor $\mathrm{X}$ of the common pathway (Table II). This IDL- or HDL-induced activity was only Factor IIdependent, and suggested that prothrombin was converted to thrombin by a direct prothrombin activator.

This was confirmed by assaying prothrombin cleavage directly. Cell homogenates prepared from PBM incubated with the stimulatory lipoproteins or LPS were added to ${ }^{125} \mathrm{I}$-prothrombin in the presence of $25 \mathrm{mM} \mathrm{CaCl}{ }_{2}$ for $30 \mathrm{~min}$ at $37^{\circ} \mathrm{C}$. Prothrombin cleavage was assessed by SDS-PAGE of the reaction mixtures followed by autoradiographic display (Fig. 3).
Smaller molecular weight cleavage products of ${ }^{125} \mathrm{I}$ prothrombin were obtained from PBM cell homogenates stimulated with HDL (Fig. 3) and IDL (not shown), whereas no direct prothrombin cleavage was observed with either LPS- or VLDL-stimulated PBM cell homogenates. The HDL- or IDL-induced prothrombin cleavage products, although qualitatively similar to those generated by isolated human Factor $\mathrm{Xa}$, did not appear to be precisely identical (Fig. 3). Furthermore, both viable cells and cell homogenates of IDL- or HDL-stimulated PBM, when added to isolated prothrombin and fibrogen in the presence of $\mathrm{CaCl}_{2}$, initiated the formation of a fibrin clot (Table IV). Although expressed by viable cells, this PCA was not present in the 100,000 -g supernatant medium of stimulated cells, but was found in the pellet of cellular material, which suggests that it is cell associated. Thus, these IDL- and HDL-stimulated PBM contained an enzyme which cleaved prothrombin, and the products of this cleavage were functionally active. Homogenates of control cells, or VLDL- and LPS-stimulated cells,

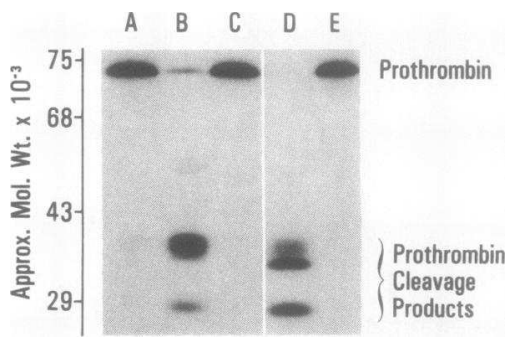

FIgURE 3 HDL-induced cellular PCA can directly cleave prothrombin as shown by the autoradiograph of an SDS polyacrylamide electrophoresis slab gel. Lanes contain reaction mixtures from the $37^{\circ} \mathrm{C}, 30$-min incubation of ${ }^{125} \mathrm{I}$-prothrombin and $\mathrm{CaCl}_{2}$ with cell homogenates of $10^{6} \mathrm{PBM}$ which had been incubated for $14 \mathrm{~h}$ at $37^{\circ} \mathrm{C}$ with: (A) $190 \mu \mathrm{g}$ of VLDL; (B) 1975 $\mu \mathrm{g}$ of HDL; (C) $10 \mu \mathrm{g}$ of LPS; (D) $80 \mathrm{ng}$ of isolated human Factor $\mathrm{Xa}$ or (E) lipoprotein buffer control. Only cell homogenates from PBM stimulated with HDL were capable of generating prothrombin cleavage products similar to those obtained by direct Xa cleavage. 
were not able to initiate clotting in this prothrombinfibrinogen system (Table IV). Similarly, neither the cell homogenates nor Factor Xa clotted fibrinogen in the absence of prothrombin (data not shown).

The identity of the cellular PCA induced by IDL and HDL was further examined with respect to neutralization by anti-Factor $\mathrm{X}$ antibody. The IgG fraction of a rabbit antiserum to human Factor $\mathrm{X}$ markedly attenuated the cleavage of ${ }^{125} \mathrm{I}$-prothrombin by Factor $\mathrm{Xa}$, and therefore contained neutralizing antibody for Factor Xa activity. This same antibody, however, did not attenuate the cleavage of ${ }^{125} \mathrm{I}$-prothrombin by the PCA present in the cell homogenates of IDL- or HDLstimulated PBM (Table V). Similarly, when functional direct prothrombin activation was tested by observing clot formation in the presence of $\mathrm{CaCl}_{2}$, prothrombin, and fibrinogen, the anti-Factor X IgG neutralized Factor Xa activity (assayed in the presence of unstimulated cell homogenates), but did not neutralize the IDL- or HDL-induced cellular PCA (data not shown).

We next examined the ability of protease inhibitors to prevent ${ }^{125} \mathrm{I}$-prothrombin cleavage by purified Factor $\mathrm{Xa}$, and by IDL- and HDL-induced cellular PCA (Table VI). Whereas $>80 \%$ inhibition of Factor $\mathrm{Xa}$ activity was observed with antithrombin III in the presence of heparin, soybean trypsin inhibitor, and phenyl-methylsulfonyl fluoride, none of these inhibited the cellular prothrombin cleaving activity. In contrast, Factor Xa was much less sensitive to diisopropylfluorophosphate than was the cellular prothrombin cleaving activity (Table VI). These combined data suggest that the IDLand HDL-induced prothrombin cleaving activity may not be Factor $\mathrm{Xa}$, but rather a serine protease.

TABLE IV

Direct Generation of Functional Thrombin by IDL and HDL-induced Cellular PCA

\begin{tabular}{lcrr}
\hline \multirow{2}{*}{$\begin{array}{c}P B M \\
\text { stimulus } 1\end{array}$} & Concentration & Viable & Total content \\
\cline { 3 - 4 } & $\mu g / m l$ & \multicolumn{2}{c}{ Clotting time* $^{*}$} \\
Buffer $\$$ & - & $>420$ & $>420$ \\
LPS & 10 & $>420$ & $>420$ \\
VLDL & 190 & $>420$ & $>420$ \\
IDL & 748 & 147 & 66 \\
LDL & 1,740 & $>420$ & $>420$ \\
HDL & 1,975 & 158 & 71 \\
\hline
\end{tabular}

* Clotting assay reaction mixtures contained only prothrombin, fibrinogen, $\mathrm{CaCl}_{2}$, and cellular test material (either viable cells or cell homogenates) as described in Methods. The addition of human Factor Xa to the "buffer" total content clotting assay reaction mixture to a final concentration of $\mathbf{8 0}$ $\mathrm{ng} / \mathrm{ml}$ gave a clotting time of $32 \mathrm{~s}$.

$\downarrow 1 \times 10^{6} \mathrm{PBM}$ in $1 \mathrm{ml}$ were cultured for $6 \mathrm{~h}$ at $37^{\circ} \mathrm{C}$ in RPMI 1640 and washed.

\$ Lipoprotein buffer control (LLB).
TABLE V

Anti-Factor X IgG Inhibits ${ }^{125}$ I-Prothrombin Cleavage by

Human Factor Xa but Not by Human PBM that Have Been Stimulated with HDL or IDL

\begin{tabular}{lccc}
\hline \multirow{2}{*}{ Source activity } & & \multicolumn{2}{c}{${ }^{\text {125I-Prothrombin cleavage* }}$} \\
\cline { 3 - 4 } & Time & Normal IgG & Anti-factor IgG! \\
\hline \multirow{2}{*}{ Factor Xa $\S$} & $h$ & \multicolumn{2}{c}{$\%$} \\
& 0 & 22.2 & 34.5 \\
PBM incubated with & 0 & 50.6 & 3.2 \\
IDL" & 6 & 29.1 & 50.6 \\
PBM incubated with & 0 & 46.5 & 45.8 \\
HDL" & 6 & 38.9 & 51.9 \\
\hline
\end{tabular}

* Reaction mixtures containing homogenates of unstimulated $\mathrm{PBM}$ and ${ }^{125} \mathrm{I}$-prothrombin were used as control. No cleavage was observed.

$\$ 1 \mathrm{mg} / \mathrm{ml}$ of IgG fraction of normal rabbit serum or rabbit anti-human Factor X (where $100 \mu \mathrm{l}$ had the capacity to neutralize $31.25 \mu \mathrm{g}$ of Factor $\mathrm{Xa}$ ).

$\S 0.5 \mu \mathrm{g} / \mathrm{ml}$ human Factor $\mathrm{Xa}$ added to the cell homogenate $10^{6}$ unstimulated PBM.

"Cell homogenates of $1 \times 10^{6} \mathrm{PBM}$ which had been incubated for $10 \mathrm{~h}$ with $50 \mu \mathrm{g} / \mathrm{ml}$ IDL or $500 \mu \mathrm{g} / \mathrm{ml} \mathrm{HDL}$.

\section{DISCUSSION}

This study provides evidence for a previously unrecognized reciprocal regulatory network whereby differing plasma lipoproteins can, through interaction with peripheral blood mononuclear cells, initiate or suppress cellular procoagulant activities. This study further indicates that certain plasma lipoproteins are potent stimulants of PBM-derived PCA. The normal concentration ranges of these lipoproteins in plasma are $70-180,80-120,725-840$, and $1,300-1,600 \mu \mathrm{g}$ lipoprotein protein/ml for VLDL, IDL, LDL, and HDL, respectively (26). Among these lipoprotein density classes, IDL appeared to be the most potent procoagulant stimulant on a protein basis with maximal activity at $50 \mu \mathrm{g}$ protein/ml. HDL was a similarily potent stimulant at a 10 -fold higher protein concentration, whereas VLDL induced lesser amounts of PCA at protein concentrations identical to those of IDL. Whether these biological activities reside in the major lipoproteins of these classes or in minor lipoprotein subclasses is a topic for study. Procoagulant activity was expressed by viable cells, indicative of either cellsurface expression or secretion but $>85 \%$ of the activity was observed only after the cells were disrupted, which suggests the existence of a predominant functionally active intracellular pool.

Both the magnitude and the substrate requirements of the PCA induced by VLDL differed from that induced by either IDL or HDL. VLDL-induced PCA, like LPS-induced PCA, appeared to be a classical 
TABLE VI

Inhibition of IDL- or HDL-induced PCA and Human Xa Proteolytic Activity by Various Agents

\begin{tabular}{|c|c|c|c|}
\hline \multirow[b]{2}{*}{ Protease inhibitor* } & \multicolumn{3}{|c|}{$\begin{array}{l}\text { Inhibition of }{ }^{125} \text { I-prothrombin } \\
\text { cleavage }\end{array}$} \\
\hline & $\begin{array}{c}\text { Factor } \\
\text { Xat }\end{array}$ & $\begin{array}{l}\text { IDL- } \\
\text { induced } \\
\text { PCA } \$\end{array}$ & $\begin{array}{l}\text { HDL } \\
\text { induced } \\
\text { PCA } \$\end{array}$ \\
\hline & & $\%$ & \\
\hline Buffer" & $<3$ & $<3$ & $<3$ \\
\hline $\begin{array}{l}\text { Antithrombin III }(19 \mu \mathrm{g} / \mathrm{ml}) \\
\text { plus heparin }(1 \mathrm{U} / \mathrm{ml})\end{array}$ & 80 & $<3$ & $<3$ \\
\hline Trasylol $(10 \mathrm{U} / \mathrm{ml})$ & $<3$ & $<3$ & $<3$ \\
\hline $\begin{array}{l}\text { Soybean trypsin inhibitor } \\
\qquad(10 \mu \mathrm{g} / \mathrm{ml})\end{array}$ & 97 & $<3$ & $<3$ \\
\hline Benzamidine (1 mM) & 8 & $<3$ & 4 \\
\hline $\begin{array}{l}\text { Phenylmethylsulfonyl fluoride } \\
\text { (1 } \mathrm{mM})\end{array}$ & 82 & 5 & 5 \\
\hline $\begin{array}{l}\text { Diisopropylfluorophosphate } \\
(2.5 \mathrm{mM})\end{array}$ & $<3$ & 95 & 97 \\
\hline $\begin{array}{l}\text { Diisopropylfluorophosphate } \\
(10 \mathrm{mM})\end{array}$ & 40 & 97 & 97 \\
\hline
\end{tabular}

* The reaction mixtures were incubated for $5 \mathrm{~min}$ at $22^{\circ} \mathrm{C}$ with the inhibitor before prothrombinase activity was measured by the addition of $\mathrm{CaCl}_{2}$ and ${ }^{125} \mathrm{I}$-prothrombin.

\$ Factor $\mathrm{Xa}(0.5 \mu \mathrm{g} / \mathrm{ml})$ was added to the cell homogenate of $10^{6}$ unstimulated PBM.

$\$$ Homogenate of $10^{6} \mathrm{PBM}$ which had been incubated with $50 \mu \mathrm{g} / \mathrm{ml}$ of IDL or $500 \mu \mathrm{g} / \mathrm{ml}$ of HDL for $10 \mathrm{~h}$.

" $0.01 \mathrm{M}$ Tris, $0.14 \mathrm{M} \mathrm{NaCl}, \mathrm{pH}$ 7.4.

tissue factor activity that was dependent upon Factor VII of the extrinsic coagulation pathway, and which did not directly cleave prothrombin. In contrast, IDLand HDL-induced PCA did not appear to require plasma coagulation factors of either the extrinsic or intrinsic pathways, but did require prothrombin for resultant clotting of fibrinogen. The differences in the type of PCA induced by IDL and HDL, in contrast to VLDL, may in part account for the distinct differences we observed in the capacity of IDL or HDL to stimulate larger increases in PCA than can VLDL (Figs. 1 and 2).

The cellular PCA induced by IDL or HDL appeared to directly cleave prothrombin in the absence of other added coagulation proteins; and the products of prothrombin cleavage were functionally thrombinlike in their capacity to convert fibrinogen to fibrin. The prothrombin cleavage products of IDL- and HDLinduced PCA were similar though not necessarily identical to those obtained with human plasma Factor Xa when characterized by SDS-PAGE. Two characteristics of IDL- and HDL-induced cellular PCA demonstrate that it is distinct from tissue factor, which is induced in human peripheral blood mononuclear cells by other described stimuli and by VLDL: $(a)$ its ability to induce clotting in hereditary Factor VII- or
Factor X-deficient plasmas, and $(b)$ its capacity to generate functional thrombinlike products proteolytically from prothrombin. Such maneuvers define the expression by these cells of two forms of inducible PCA, but do not at this point establish the molecular characteristics of the inducible prothrombinase. A series of observations suggests that it is not free Factor $\mathrm{Xa}$. Free Factor $\mathrm{Xa}$ was not detectable by radioimmunoassay (23) in quantities $<0.2 \%$ of that required for equivalent prothrombin cleavage. In addition, the cellular prothrombinase was not neutralized by antiFactor Xa antibodies, antithrombin III in the presence of heparin, phenylmethyl-sulfonyl fluoride, or soybean trypsin inhibitor, a particularly potent inhibitor of Factor Xa. It was, however, more sensitive than Factor $\mathrm{Xa}$ to diisopropylfluorophosphate, and was not sensitive to other protease inhibitors that included benzamidine and trasylol.

The fact that antithrombin III plus heparin did not inhibit the activity of the IDL- and HDL-induced cellular prothrombinase does not exclude the possibility of a cell-associated Va-Xa prothrombinase complex comparable with that observed on the surface of activated platelets $(27,28)$. This complex is not neutralized by antithrombin III, even in the presence of heparin. This particularly provocative possibility is difficult to exclude in light of the profound amplification of Factor $\mathrm{Xa}$ activity produced by complex formation in association with a platelet surface, i.e., $3 \times 10^{5}$-fold $(28,29)$. Whether such complexes can survive cellular disruption employed in this study is not known. The lack, however, of any neutralization by antibody (Table V) or by protease inhibitors, such as soybean trypsin inhibitor or phenylmethylsulfonyl fluoride (Table VI), suggests that this complex may be distinct from the Va-Xa complex, and may provide phenotypic characterization of a cell-associated prothrombinase that will require further study. Regardless of the ultimate identity of this lipoproteininduced PCA, it appears different from other described cellular PCA.

Special consideration was given to the possibility that these in vitro observations might be physiologically trivial rather than representative of physiologically or pathologically significant events. During the course of these studies, lipoproteins from six different isolations were employed, and all preparations were comparable. The possibility that the regulation of PCA expression was dependent upon contaminating coagulation factors present in reagents or lipoproteins has been excluded, as has the effect of fetal calf serum used for cell culture, after observation of full induction and suppression of PCA in the absence of serum in the medium. Possible endotoxin contamination of the lipoproteins has been rigorously examined using the limulus assay (19) and the mouse lethality test (18). LPS, if present, must be so at concentrations 
less than $1 \mathrm{ng} / \mathrm{mg}$ of lipoprotein protein. We have also attempted to exclude in vivo or experimental LPS contamination of the stimulating lipoproteins as a plausible explanation for the phenomenon. First, even though LPS or bacterial endotoxins have been found associated with plasma lipoproteins, this association appears to be specific to HDL (30). Second, the nature of the IDL- and HDL-inducible PCA was distinct from that described for either LPS (2) or other reported stimuli.

The present study demonstrates that plasma VLDL, IDL, and HDL classes can induce a dose- and timedependent expression of two types of PCA in cultured human PBM, whereas LDL cannot. In addition, small amounts of LDL can inhibit, in a dose-dependent manner, the amplification of cellular PCA induced by either VLDL, IDL, or HDL. Thus the reconstituted mixture of all four lipoprotein classes which represents an approximate relative physiological mixture has little if any capacity to induce cellular PCA in vitro. PBM circulate in plasma in the presence of all of these lipoproteins, and dose-dependent thresholds were observed for both the stimulation and the inhibition of PCA expression. Since these cells are not actively expressing maximal levels of PCA as recovered from the blood (Fig. 1), and are subject to stimulation in vitro, it appears that one or more reversible physiological influences may maintain the system in a latent state in vivo. As a number of modes of initiating and dampening the coagulation system are known to occur in vivo, it is hypothesized that perturbations of plasma lipoprotein-regulated cellular PCA expression might play a role in certain hemostatic and thrombotic diseases.

The results of this study suggest that in physiological states associated with systemic or localized extravascular changes in the relative proportions of different plasma lipoproteins, critical lipoprotein concentrationdependent activation or inhibition of cellular PCA expression can occur. In this respect, no satisfactory mechanism has been brought forward to explain a variety of observed correlations between increased incidence of thrombogenesis and altered proportions of certain plasma lipoproteins. For example, a side effect of estrogen therapy, particularly associated with the use of oral contraceptives, is an increased incidence of venous thromboembolic disease and cerebral thrombosis (31). An increase in morbidity and mortality from these conditions of about sixfold has been reported. In such individuals significant changes in plasma lipoproteins also have been observed. Estrogen therapy has been demonstrated to decrease plasma LDL and total cholesterol, and to increase plasma HDL cholesterol (32). Whether these effects include increases of specific lipoproteins sufficient to stimulate PCA generation, and to decrease lipoproteins that inhibit PCA generation, merits study.

An increased incidence of thrombotic events is also observed in patients with certain hyperlipoproteinemias (33). Lipoproteins isolated from certain hyperlipoproteinemic plasma appear to accelerate some clotting tests (9); and an increased incidence of accelerated intravascular coagulation occurs in the common type IV hyperlipoproteinemia, which is characterized by increased concentrations of VLDL (34). This form of hyperlipoproteinemia has not been associated with elevated platelet sensitivity as occurs in type II hyperlipoproteinemia (34). Whether VLDLinduced cellular PCA stimulation might be involved in the apparent nonplatelet-associated heightened intravascular coagulation will merit analysis. Finally, a satisfactory explanation of the pathogenesis of atherosclerosis continues to be elusive. Lipid deposition in vascular intimal smooth muscle cells in the presence of macrophages or foam cells, and local appearance of fibrin are prominent features of the atherosclerotic lesion $(35,36)$. Whether perturbations of the lipoprotein-regulated network of monocyte activation to produce PCA may participate in the generation or progression of these lesions deserves consideration.

The implication of the present study that there is a biological relationship between plasma lipoproteins, lymphoid cells, and the coagulation system is not without precedent. In certain immunologically mediated tissue lesions such as the delayed cutaneous hypersensitivity reaction (37), kidney allograft rejection (38), experimental antiglomerular basement membranetype glomerulonephritis (39), and experimental allergic encephalitis (40), there is strong evidence that local activation of the coagulation system is a characteristic feature of the lesions in vivo. In these lesions, accumulations of mononuclear cells are prominent. In separate studies it has been observed that plasma lipoproteins can regulate lymphocyte function in vitro and in vivo (11-14). To our knowledge, however, the present study represents the first linkage of all three systems. The details of the cellular requirements and analysis of the role of plasma lipoproteins in the regulation of cellular PCA generation are considered in the accompanying study.

\section{ACKNOWLEDGMENTS}

We wish to thank Shu-Lan Cheng for her excellent technical help and Sandy Thompson for preparation of the manuscript.

This work was supported by grants from the National Institutes of Health (CA-14346, CA-28116, HL-16411, and AI14921), training grant HL-07195, and a fellowship from the Medical Research Council of Canada.

\section{REFERENCES}

1. Rickles, F. R., J. A. Hardin, F. A. Pitlick, L. W. Hoyer, and M. E. Conrad. 1973. Tissue factor activity in lymphocyte cultures from normal individuals and patients with hemophilia A. J. Clin. Invest. 52: 1427-1434.

2. Neimetz, J., T. W. Muhlfelder, E. Chierego, and B. Troy. 
1977. Procoagulant activity of leukocytes. Ann. N.Y. Acad. Sci. 283: 208-217.

3. Levy, G. A., and T. S. Edgington. 1980. Lymphocyte cooperation is required for amplification of macrophage procoagulant activity. J. Exp. Med. 151: 1232-1243.

4. Rothberger, H., T. S. Zimmerman, H. L. Spiegelberg, and J. H. Vaughan. 1977. Leukocyte procoagulant activity. Enhancement of production in vitro by IgG and antigenantibody complexes. J. Clin. Invest. 59: 549-557.

5. Wadell, J., N. L. Johnson, J. G. Pool, and W. P. Creger. 1966. Thromboplastin activity in cultured blood leukocytes. Clin. Res. 14: 169. (Abstr.)

6. Muhlfelder, T. W., J. Niemetz, D. Kreutzer, D. Beebe, P. A. Ward, and S. I. Rosenfeld. 1979. C5 chemotactic fragment induces leukocyte production of tissue factor activity, a link between complement and coagulation. J. Clin. Invest. 63: 147-150.

7. Nemerson, Y., and F. A. Pitlick. 1972. The tissue factor pathway of blood coagulation. Prog. Hemostasis Thromb. 1: 1-37.

8. Davie, E. W., and D. J. Hanahan. 1977. Blood Coagulation Proteins. In The Plasma Proteins. F. W. Putnam, editor. Academic Press, Inc., New York. 3: 421-544.

9. Vijayagopal, P., and N. G. Ardlie. 1978. Coagulant activity of human plasma lipoproteins from normal and hyperlipidemic subjects. Thromb. Res. 12: 721-733.

10. Sanberg, H., and L. O. Andersson. 1976. Studies on the thromboplastic effect of human plasma lipoproteins. Thromb. Haemostasis. 35: 178-185.

11. Curtiss, L. K., and T. S. Edgington. 1976. Immunoregulatory serum lipoproteins. Regulation of lymphocyte stimulation by a species of low density lipoproteins. J. Immunol. 116: 1452-1458.

12. Chisari, F. V. 1977. Immunoregulatory properties of human plasma in very low density lipoproteins. J. Immunol. 119: 2129-2136.

13. Morse, J. H., L. D. Witte, and D. S. Goodman. 1977. Inhibition of lymphocyte proliferation stimulated by lectins and allogeneic cells by normal plasma lipoproteins. J. Exp. Med. 146: 1791-1803.

14. Curtiss, L. K., D. H. DeHeer, and T. S. Edgington. 1980. Influence of an immunoregulatory serum lipoprotein (LDL-In) on the in vivo differentiation and proliferation of antigen-binding and antibody-secreting lymphocytes during a primary immune response. Cell. Immunol. 49: $1-11$.

15. Havel, R. J., H. S. Eder, and J. H. Bvagdon. 1955. The distribution and chemical composition of ultracentrifugally separated lipoproteins in human serum. J. Clin. Invest. 34: 1345-1353.

16. Markwell, M. A. K., S. M. Haas, L. L. Bieber, and N. E. Tolbert. 1978. A modification of the Lowry procedure to simplify protein determination in membrane and lipoprotein samples. Anal. Biochem. 87: 206-210.

17. Noble, R. P. 1968. Electrophoretic separation of plasma lipoprotein in agarose gel. J. Lipid Res. 9: 693-700.

18. Morrison, D. C., J. A. Louis, and W. O. Weigle. 1976. Dissociation of anticomplementary and adjuvant properties of proteins derived from cobra venom. Immunology. 30: 317-323.

19. Levin, J., P. A. Tomasulo, and R. S. Oser. 1970. Detection of endotoxin in human blood and demonstration of an inhibitor. J. Lab. Clin. Med. 75: 903-911.

20. Boyum, A. 1976. Isolation of lymphocytes, granulocytes and macrophages. Scand. J. Immunol. 5(Suppl.): 5-15.

21. Li, C. Y., K. W. Lam, and L. T. Yam. 1973. Esterases in human leukocytes. J. Histochem. Cytochem. 21: 1-12.
22. Davey, F. R. 1979. Blood coagulation and its disorders In Clinical Diagnosis and Management by Laboratory Methods. J. B. Henry, editor. W. B. Saunders Co., Philadelphia. 1131-1170.

23. Fair, D. S., E. F. Plow, and T. S. Edgington. 1979. Combined functional and immunochemical analysis of normal and abnormal human Factor X. J. Clin. Invest. 64: 884-894.

24. Doolittle, R. F., D. S. Schubert, and S. A. Schwartz. 1967. Amino acid sequence studies on artiodactyl fibrinopeptides. Arch. Biochem. Biophys. 118: 456-467.

25. Laemmli, U. K. 1970. Cleavage of structural proteins during the assembly of the head of bacteriophage T4. Nature (Lond.). 227: 680-685.

26. Fredrickson, D. S., and R. I. Levy. 1972. Familial hyperlipoproteinemia In The Metabolic Basis of Inherited Disease. 3rd edition. J. B. Stanburg, editor. McGraw-Hill Book Company, New York. 545-614.

27. Miletich, J. P., C. M. Jackson, and P. W. Majerus. 1977. Interaction of coagulation Factor Xa with human platelets. Proc. Natl. Acad. Sci. U. S. A. 74: 4033-4036.

28. Miletich, J. P., C. M. Jackson, and P. W. Majerus. 1978 Properties of Factor Xa binding site on human platelets. J. Biol. Chem. 253: 6908-6916.

29. Dahlback, B., and J. Stenflo. 1978. Binding of bovine coagulation factor $\mathrm{Xa}$ to platelets. Biochemistry. 17: 4938-4945.

30. Ulevtich, R. J., A. R. Johnson, and D. B. Weinstein. 1979. New functions for high density lipoproteins. Their participation in intravascular reactions of bacterial lipopolysaccharides. J. Clin. Invest. 64: 1516-1524.

31. Doar, J. W. H. 1973. Metabolic side-effects of oral contraceptives. Clin. Endocrinol. Metab. 22: 503-525.

32. Bostofte, E., L. Hemmingsen, K. J. Alling-Moller, J. Serup, and T. Weber. 1978. Serum lipids and lipoproteins during treatment with oral contraceptives containing natural and synthetic oestrogens. Acta Endocrinol. 87: 855-864.

33. Lees, R. S., and A. M. Lees. 1976. Therapy of the hyperlipidemias. Postgrad. Med.J. 60: 99-107.

34. Carvalho, A. C., R. S. Lees, R. A. Vaillancorut, R. B. Cabral, R. M. Weinberg, and R. W. Colman. 1976. Intravascular coagulation in hyperlipidemia. Thromb. Res. 8: 843-857.

35. Scotti, T. M. 1977. Heart. In Pathology. 7th edition W. A. D. Anderson and J. M. Kissane, editors. The C. V. Mosby Co., St. Louis, Mo. 757-766.

36. Schaffner, T., K. Taylor, E. J. Bartucci, K. FischerDzoga, J. H. Beeson, S. Glagov, and R. W. Wissler, 1980. Arterial foam cells with distinctive immunomorphologic and histochemical features of macrophages. Am.J. Pathol. 100: 57-73.

37. Colvin, R. B., and H. F. Dvorak. 1975. Role of the clotting system in cell mediated hypersensitivity. II. Kinetics of fibrinogen/fibrin accumulation and vascular permeability changes in tuberculin and cutaneous basophil hypersensitivity reactions. J. Immunol. 14: 377-387.

38. Busch, G. J., E. S. Reynolds, E. G. Galvanef, W. E. Braun, and G. J. Dammin. 1971. Human renal allografts: the role of vascular injury in early graft failure. Medicine (Baltimore). 50: 29-83.

39. Vassalli, P., and R. T. McCluskey. 1964. The pathogenic role of fibrin deposition in immunologically-induced glomerulonephritis. Ann. N. Y. Acad. Sci. 116: 10521062.

40. Paterson, P. Y. 1976. Experimental allergic encephalomyelitis: role of fibrin deposition in immunopathogenesis of inflammation in rats. Fed. Proc. 35: 2428-2434. 